\title{
A combined experimental and simulation method for appraising the energy performance of green roofs in Ningbo's Chinese climate.
}

\author{
Georgios Kokogiannakis ${ }^{\mathrm{a}}$, Jo Darkwa ${ }^{\mathrm{a}}$, Kate Yuan ${ }^{\mathrm{a}}$ \\ ${ }^{a}$ Centre for Sustainable Energy Technologies (CSET), The University of Nottingham, \\ 199 Taikang East Road, Ningbo, 315100 China
}

Corresponding author: Georgios Kokogiannakis

Corresponding email address: georgios.kokogiannakis@nottingham.edu.cn

Postal address of all authors: Centre for Sustainable Energy Technologies (CSET), The University of Nottingham, 199 Taikang East Road, Ningbo, 315100 China

Telephone for Author "Georgios Kokogiannakis": +86 57488180929

Telephone for Author "Jo Darkwa": +86 57488180255

Telephone for Author "Kate Yuan": +86 57488180367

Fax of all authors: +8657488180313

Email address for Author "Georgios Kokogiannakis":

georgios.kokogiannakis@nottingham.edu.cn

Email address for Author "Jo Darkwa": jo.darkwa@nottingham.edu.cn

Email address for Author "Kate Yuan”: kate.yuan@nottingham.edu.cn

\section{Acknowledgements}

The authors would like to thank Ningbo Science \& Technology Bureau for funding this study as part of a Soft Science project (Grant No. 2011A1051) and the National Natural Science Foundation of China (NSFC) for also supporting this study (Grant No. 51208271). 


\title{
A combined experimental and simulation method for appraising the energy performance of green roofs in Ningbo's Chinese climate.
}

\begin{abstract}
A passive means of lowering the energy demand of buildings is the application of green roofs. The complexity between heat and moisture exchanges in green roof layers and the large variations of green roof types make the need for experimental or simulation assessments necessary for quantifying the energy benefits from green roofs. The current treatment of green roofs in simulation programs is either over-simplistic, for example by ignoring heat and moisture exchanges such as evapotranspiration, or the more advanced models have limitations and require inputs that are rarely available in practice. In this paper a combination of experimental and modelling techniques are used to assess the potential heating and cooling load reductions from the application of green roofs in the subtropical climate of Ningbo in China. The method provides a generalised energy performance assessment of green roofs in Ningbo by overcoming the limitations of existing green roof simulation models.
\end{abstract}

Keywords: Green roofs; energy and carbon savings; integrated building energy simulation; measuring boundary conditions

\section{Introduction}

Building energy regulations are continuously evolving across the world with the aim of introducing additional measures that could further reduce the energy consumption of buildings. A potential technique for lowering energy consumption in buildings is the application of green roofs. The benefits from green roofs have been extensively discussed in various literatures and are not limited to only lowering the energy demand. Green roofs are linked with other socio-economic issues such as storm water management (Mentens et al. 2006, Teemusk and Mander 2007), mitigation of urban heat island (Alexandri and Jones 2008, Susca et al. 2011), enhancement of biodiversity 
(Brenneisen 2003), improvements on air quality (Yang et al. 2008), etc. The overall advantages of green roofs have been discussed by many researchers (e.g. Banting et al. 2005). A thorough review of previous studies in which the energy savings that could be offered from green roofs were investigated is given by Castleton et al. (2010). Most of these previous studies that have been reviewed by Castleton et al. (2010) were focused on extensive green roofs and the authors concluded that green roofs could mainly offer energy savings to buildings with poor insulation levels. The conclusion by Castleton et al. (2010) was obtained from previous studies that were done for green roofs located in Mediterranean, North American and hot Asian (i.e. Singapore) climates. The paper presented here is concerned with the potential energy savings that green roofs could offer in buildings located at Ningbo in China, under a climate that has hot rainy summers and cold dry winters and belongs to the sub-tropical "hot summer and cold winter" climate zone of China. The assessments for the potential energy savings of green roofs in this climate will be done by introducing in this paper a method that combines experimental and simulation techniques together to overcome potential practical limitations of these techniques. Such limitations will be discussed in this section while the proposed method will be described in section 2 of this paper.

A classic method in the literature for assessing the energy benefits from green roofs is by using on-site experimental set-ups. Measurements are taken of the heat flux and the temperatures across the green roof layers while in some cases there is also an analysis of the different heat and moisture exchanges in the canopy and soil layers (e.g. convection in the canopy, evaporation of leaves, etc). For example, Jim and Tsang (2011) used temperature sensors on an intensive green roof with trees on top of a building in Hong Kong in order to verify that green roofs offer energy savings and investigate what effect the physical and biological processes of the green roof layers 
may have on the overall energy performance of the green roof construction. Wong et al. (2003) took also measurements on a rooftop of a low-rise commercial building in Singapore and confirmed that green roofs offer thermal benefits to the indoor spaces of the building while they also analysed the contribution of the vegetation and the soil layers to these thermal benefits. Onmura et al. (2001) did also measure experimentally the surface temperature reduction that was offered by a roof lawn garden on a building in Osaka, Japan during the summer and found that the green roof could reduce external surface roof temperatures during the summer by about $30^{\circ} \mathrm{C}$.

The main disadvantages of the experimental green roof assessments are that they are expensive, time consuming and the conclusions are only accurate for the specific building under testing while attempts to generalise these conclusions for other buildings would not account for the uncertainties and the dynamics in the indoor spaces below the roof. Dynamic building energy modelling does offer an alternative method for assessing the energy benefits of building technologies across a variety of building types and climates. The use of building simulation programs could address some of the drawbacks of the experimental methods and there has been significant work done over the last decades on validating these programs, e.g. a summary of previous validation studies for the ESP-r program is given by Strachan et al. (2008). However, the development of green roof models that are accurate and integrated with whole building energy simulation models is currently limited and the inputs needed for such assessments are often difficult to obtain or may involve uncertainty. The most significant work in the area was done with the development of a green roof model in the EnergyPlus whole building simulation program (Sailor 2008) and it has been recently reported in the literature that the same model has also been used within the TRNSYS simulation tool (Jaffal et al. 2012). The specific model has some limitations, for example it cannot 
model time variable plant thermal and physical properties (e.g. time variable plant height and leaf growth) and there are also uncertainties in obtaining some of its data inputs. It is however, currently the most detailed model within a whole building simulation program. Stand-alone model development and numerical analysis of green roof layers (i.e. independent from the rest of the built environment) have also been reported in the literature. For example a detailed numerical model for assessing the cooling potential of green roofs was presented by Palomo (1998) while several other authors presented sets of equations that represent heat and moisture exchanges in the green roof layers (e.g. Feng et al. 2010, Tabares-Velasco and Srebric 2012). The main disadvantage of stand-alone studies is that the calculations ignore the dynamics and the operational characteristics of the building where the green roof is installed and complete whole building energy performance assessments are not therefore possible.

In this paper there is an attempt to overcome the practical disadvantages of both experimental and simulation methods with regard to the energy performance assessments of green roofs, and assess carbon reductions and energy savings from green roofs in Ningbo's climate with a combined approach that could be generalised and be used in several buildings types. The next section will describe this combined approach of experimental and simulation green roof energy assessments.

\section{Method of assessment}

The reductions on the heating and cooling energy requirements that could be offered by a green roof in Ningbo will be quantified by measuring weather data and temperatures in the green roof layers and by importing these measurements within the ESP-r whole building simulation program. The measurements will be used by ESP-r as boundary conditions for modelling a different building rather than the one where the green roof is 
installed. The purpose of this procedure is to establish a way to use one set of measurements and simulate different building cases that are located within the same climatic zone as where the measured data were collected from.

The experimental part of this study took place at the Centre for Sustainable Energy Technologies (CSET) building which is located at the campus of The University of Nottingham in Ningbo China. The CSET building integrates a number of building technologies including an intensive green roof on top of its laboratories spaces (Figure 1).



Figure 1. A view of the green roof on top of the lab spaces in the CSET building in Ningbo

Weather data were collected on-site and a temperature sensor was placed at a location on top of the roof's soil layer where vegetation was removed. Another temperature sensor was placed at the bottom of the soil in the green roof (400 $\mathrm{mm}$ thick). There was only light vegetation (grass, Leaf Area Index $=0.1$ ) on the roof during the period of the measurements. Figure 2 shows a diagram with the positions of the sensors. In this way the difference between the temperature of the roof without the green roof and the temperature below the soil could be measured and compared. The measured 
temperature below the soil layer includes the effect of any potential coupled moisture and energy flows that could take place within the soil during the measurements. Two sets of data could then be imported into ESP-r for further comparison of a building that is using these two different sets of boundary conditions (i.e. with roof surface temperature that varies in a same way as the two sets of measurements). In this case, the measured temperature above the soil is used for representing the surface temperature of a building without green roof against which the comparison of this study will take place. This is however a limitation since the radiative properties of the soil material (i.e. emittance and absorptance) do vary from material to material and in this study it is assumed that the coating of the roof material of the simulated building has the same radiative properties (emittance and absorptance) as the soil. Building practitioners should take into account this limitation when applying the same study in their daily practice and instead of measuring the temperature on the top of the soil, there should be a measurement for the temperature of a material that has the same absorptance and emittance as the roof material of the simulated building.



Figure 2. Cross sectional view of the green roof showing the position of the sensors

It is worth mentioning that an insulation layer $(120 \mathrm{~mm})$ thicker than the levels of local building standards is installed just below the green roof construction and any heat flows from the inner building lab spaces were minimised during the two periods of the 
measurements. The first set of measurements was taken during the heating season (from $3^{\text {rd }}$ of January to $31^{\text {st }}$ of January) and the second set was taken during the cooling season (from $1^{\text {st }}$ of July to $31^{\text {st }}$ of July). The measured ambient temperatures during the two periods of the study are shown in Figures 3 and 4 respectively where it can be seen that Ningbo has relatively cold periods in the winter and hot periods in the summer.



Figure 3. Measured ambient air temperature in Ningbo $\left(3^{\text {rd }} \mathrm{Jan}-31^{\text {st }} \mathrm{Jan}\right)$



Figure 4. Measured ambient air temperature in Ningbo $\left(1^{\text {st }} \mathrm{July}-31^{\text {st }} \mathrm{July}\right)$ 
The measured data were then imported into the ESP-r simulation program, which currently does not have a detailed green roof model, and a simulation model was prepared for the top floor of a new teaching building that is also located at the University's campus in Ningbo (Figure 5). ESP-r has a facility for importing measured climate data but there was no facility for importing measured surface temperatures. It was therefore necessary to expand the capabilities for importing measurements into ESP-r and use ESP-r's flexible open source structure to develop an option that replaces the calculated temperatures for a surface's external node with measured surface temperatures (a generic illustration of the method is given in Figure 6). The measured temperatures on top CSET's green roof included the effects of external radiation and external convection and it was therefore essential to eliminate re-simulating and accounting for such effects during the simulations. This was ensured for the simulated cases in ESP-r by turning the external convection coefficient of the roof to zero and by making also zero the absorptance and emmitance of the external layer of the roof surface.
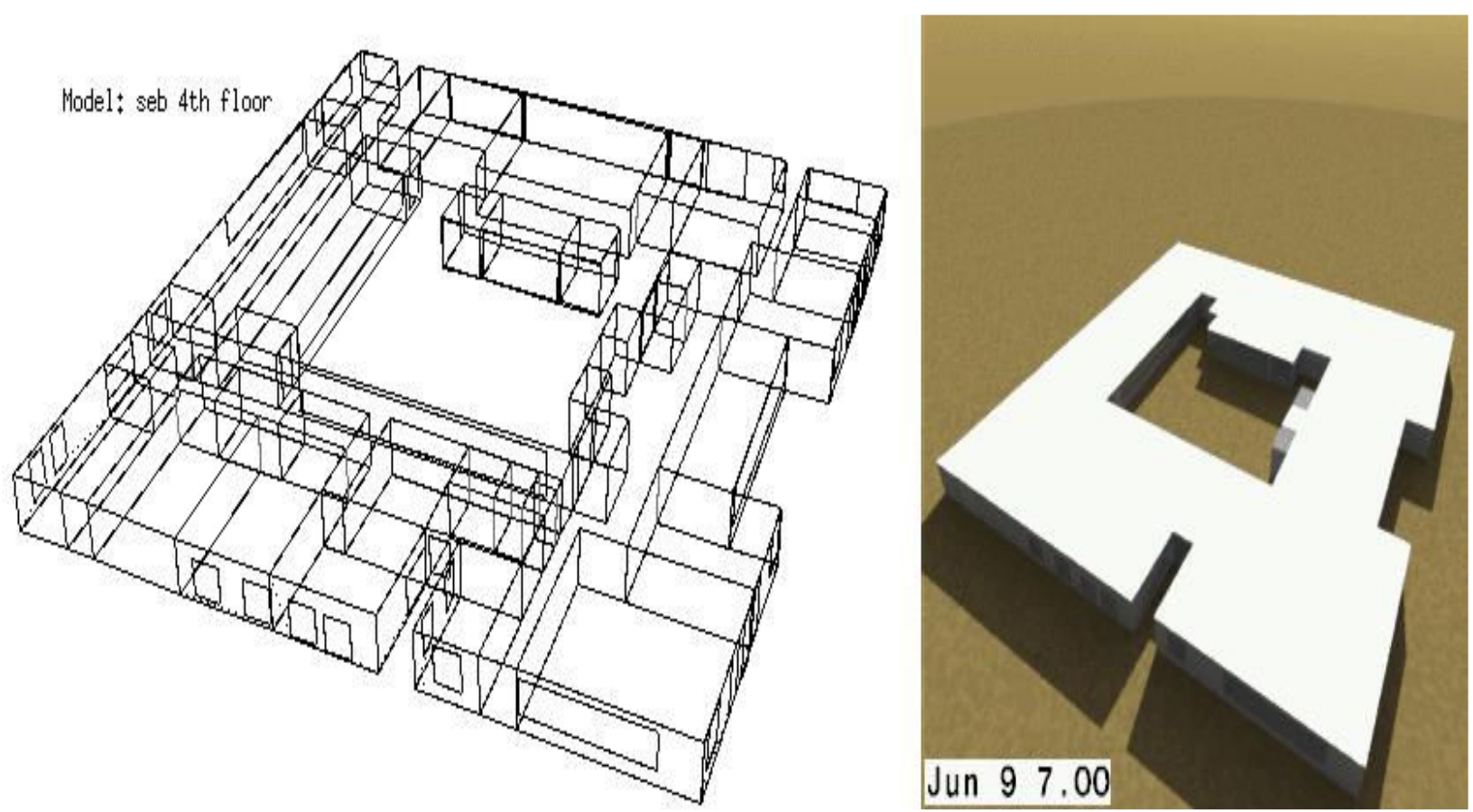

Figure 5. The building model of the study in the simulation program 




Figure 6. Control volume approach in ESP-r (Kelly, 1998) and the proposed surface temperature substitution for green roof energy performance assessment

Importing the measured data in the ESP-r simulation program will enable practitioners to take advantage of the program's existing capabilities. It will be possible to quantify the energy requirements of the building and assess the energy savings offered by the specific type of green roof in Ningbo's climate. The following four building cases were simulated for this study for both the January and the July periods (i.e. eight simulation cases in total):

(1) Uninsulated roof, without green roof

(2) Uninsulated roof, with a green roof (400 mm thick soil and light grass vegetation)

(3) $50 \mathrm{~mm}$ roof insulation, without green roof

(4) $50 \mathrm{~mm}$ roof insulation, with a green roof (400 $\mathrm{mm}$ thick soil and light grass vegetation)

The overall workflow for the combined experimental-simulation green roof assessment 
is summarised in the following diagram of Figure 7.

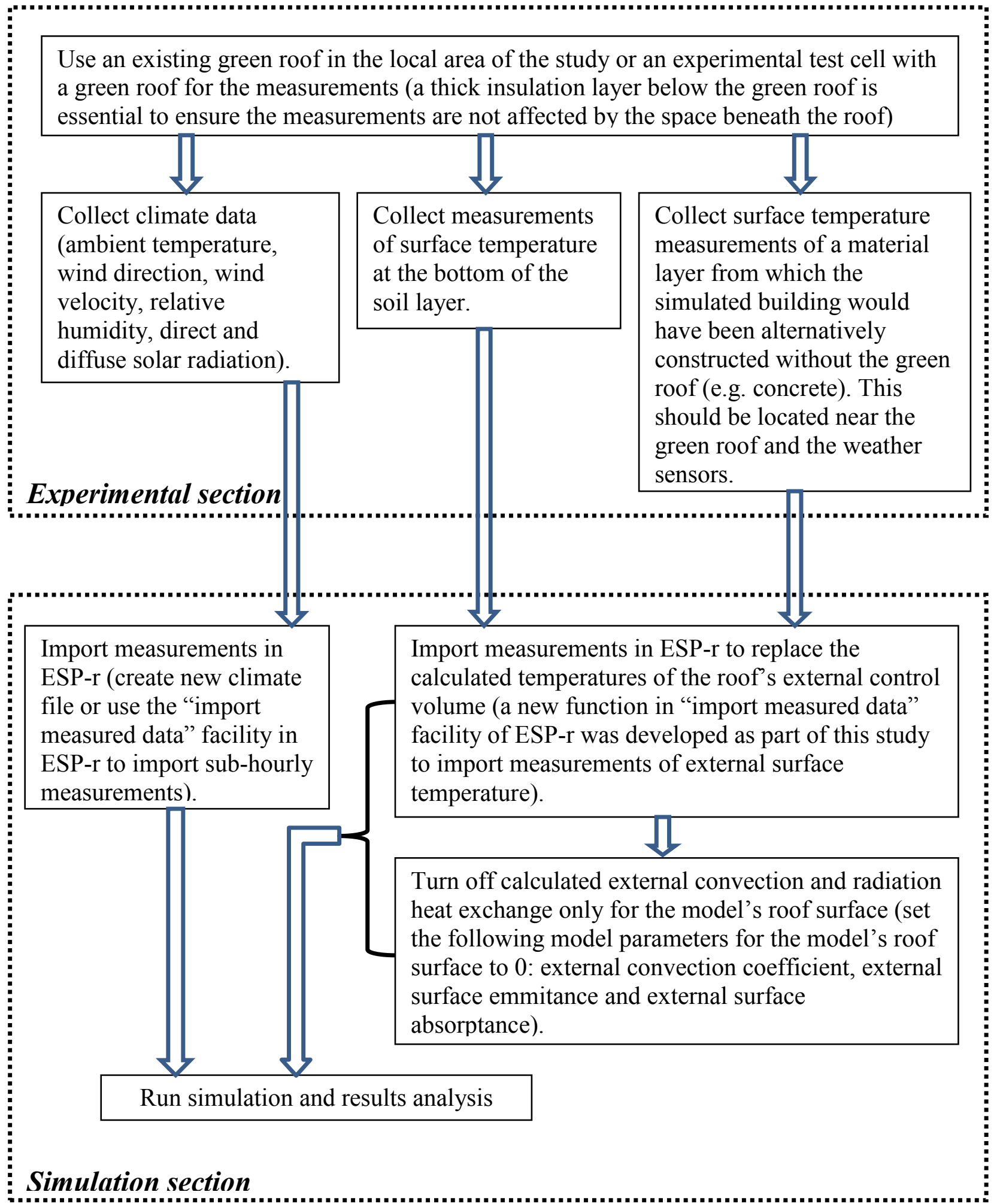

Figure 7. An overview of the process for the combined experimental-simulation green roof energy performance appraisal 


\section{Energy performance appraisal output}

The simulation results revealed significant energy savings when the green roof boundary conditions were applied on the uninsulated roof but the green roof did not offer large savings when applied on the insulated roofs. The results have been summarised in Figure 8.


Figure 8. Heating (January) and cooling (July) energy requirements for the simulated cases

It can be seen from the above graphs that a building with an intensive lightly vegetated green roof and without any other type of insulation could have less energy requirements for heating and cooling than the respective uninsulated roof building case that does not have a green roof on top (i.e. compare Case 1 versus Case $2 \&$ Case 5 vs Case 6 in Figure 8) but the savings are not as much as when a building incorporates a $50 \mathrm{~mm}$ of 
roof insulation (i.e. compare Case 2 vs Case $3 \&$ Case 6 vs Case 7 in Figure 8). In terms of heating energy requirements the results show that the green roof reduces the heating load of the building by about $19 \%$ for the uninsulated roof cases and by approximately $5 \%$ for the insulated roof cases. Significant savings could also be offered by the green roof in July. The green roof reduced the cooling energy requirements by almost $14.5 \%$ for the uninsulated roof cases but only by $1.7 \%$ for the insulated roof cases. It should be mentioned at this stage that the building of the study has adopted an intermittent heating and cooling strategy. The energy savings from the application of green roofs could be higher for buildings that have long operation hours (e.g. hotels, hospitals, etc.).

The roof of the simulated educational building is $3500 \mathrm{~m}^{2}$ and the energy for heating and cooling is generated in Ningbo by using electricity. The average daily carbon savings are also calculated for the simulated cases of this study. Estimations of carbon savings are particularly important for the area of Ningbo and the surrounding cities since the electricity is mostly generated from coal power stations and the availability of already installed renewable energy generation systems in the area is low. The conversion rate between energy $(\mathrm{kWh})$ generated by electricity and carbon dioxide emissions in China is taken from 2010 data as $0.766 \mathrm{~kg}$ of $\mathrm{CO}_{2}$ per $\mathrm{kWh}$ of electricity consumed when renewable energy sources are also included in the estimated conversion factor (IEA, 2012). The conversion factor has also been estimated for China to be 0.967 $\mathrm{kg}$ of $\mathrm{CO}_{2}$ per $\mathrm{kWh}$ of electricity consumed when only coal is assumed to be the fuel for generating electricity (IEA, 2012). Given that Ningbo's electricity demand is mainly covered by coal power stations the conversion factor of $0.967 \mathrm{~kg}$ of $\mathrm{CO}_{2}$ per $\mathrm{kWh}$ of electricity can be used in Tables 1 and 2 to calculate the average daily carbon savings from the application of green roofs on the cases of this study. 
Table 1: Average daily $\mathrm{CO}_{2}$ and Carbon savings for heating purposes per $\mathrm{m}^{2}$ of roof area (measured data collected for 29 days)

\begin{tabular}{|c|c|c|}
\hline & $\begin{array}{c}\mathrm{CO}_{2} \text { savings } \\
\left(\mathrm{kg} \mathrm{CO} / \mathrm{m}^{2} \text { per day }\right)\end{array}$ & $\begin{array}{c}\text { Carbon savings } \\
\text { (g Carbon } / \mathrm{m}^{2} \text { per day) }\end{array}$ \\
\hline $\begin{array}{l}\text { Uninsulated roof } \\
\text { Case } 2 \text { vs Case } 1\end{array}$ & 0.137 & 37 \\
\hline $\begin{array}{l}\text { Insulated roof ( } 50 \mathrm{~mm} \text { of roof insulation) } \\
\text { Case } 4 \text { vs Case } 3\end{array}$ & 0.015 & 4 \\
\hline \multicolumn{3}{|c|}{$\begin{array}{l}\text { Calculation example from the comparison of Case } 2 \text { vs Case } 1 \text { : } \\
\text {-Average daily energy savings for heating purposes per } \mathrm{m}^{2} \text { of roof area }=[(76371- \\
61948) / 3500] / 29=0.142 \mathrm{kWh} / \mathrm{m}^{2} \text { per day } \\
\text {-Average daily } \mathrm{CO}_{2} \text { savings for heating purposes per } \mathrm{m}^{2} \text { of roof area }=0.142 * 0.967=0.137 \\
\mathrm{~kg} \mathrm{CO} / \mathrm{m}^{2} \text { per day } \\
\text {-Average daily carbon savings for heating purposes per } \mathrm{m}^{2} \text { of roof area }=0.137 * 273=37 \mathrm{~g} \\
\text { carbon } / \mathrm{m}^{2} \text { per day }\end{array}$} \\
\hline
\end{tabular}

Table 2: Average daily $\mathrm{CO}_{2}$ and Carbon savings for cooling purposes per $\mathrm{m}^{2}$ of roof area (measured data collected for 31 days)

\begin{tabular}{|l|c|c|}
\hline & $\begin{array}{c}\mathrm{CO}_{2} \text { savings } \\
\left(\mathrm{kg} \mathrm{CO}_{2} / \mathrm{m}^{2} \text { per day }\right)\end{array}$ & $\begin{array}{c}\text { Carbon savings } \\
\left(\mathrm{g} \text { Carbon } / \mathrm{m}^{2} \text { per day }\right)\end{array}$ \\
\hline $\begin{array}{l}\text { Uninsulated roof } \\
\text { Case 6 vs Case 5 }\end{array}$ & 0.113 & 31 \\
\hline $\begin{array}{l}\text { Insulated roof }(50 \mathrm{~mm} \text { of roof insulation) } \\
\text { Case } 8 \text { vs Case } 7\end{array}$ & 0.01 & 3 \\
\hline
\end{tabular}

In addition, the use of the ESP-r program allows having access to a large number of performance results, including indoor air temperatures and peak thermal loads. Additional 1-day simulations were run with free float conditions (i.e. by turning off the heating and cooling supply) to identify the benefits from the green roof on reducing peak thermal loads and improving indoor temperatures. The 1-day period for the simulations was identified by investigating the periods with peak loads in the existing January and July results. The resulting indoor air temperatures for the eight model cases are presented in Figures 9 and 10 below. 




Figure 9. Sample of indoor air temperature improvements during the peak heating season



Figure 10. Sample of indoor air temperature improvements during the peak cooling season

It can be seen that indoor temperatures in the lecture hall could be increased during the peak heating period by more than $3^{\circ} \mathrm{C}$ after applying the specific green roof on an uninsulated roof (Figure 9, Cases 1 and 2). On the other hand, only minor indoor air 
temperature improvements were noticed when the green roof was applied on top of an insulated roof (Figure 9, Cases 3 and 4). A similar trend was noticed during the peak cooling season (see Figure 10, Case 5 vs Case 6 and Case 7 vs Case 8).

\section{Conclusions}

This study combined experimental with simulation techniques to overcome the limitations of the two methods in assessing the energy and carbon savings from the application of green roofs in buildings located in Ningbo's climate in China. The suggested methodology allows for energy saving appraisals of green roofs when expensive experimental appraisals are difficult to be done (e.g. during the design stage of a building) and without having to develop an advanced complex mathematical green roof model that would often require difficult to obtain inputs. The study focuses on the climate of Ningbo where an intensive green roof application was experimentally assessed and the measurements were then imported in the ESP-r simulation program to assess the potential energy and carbon savings from the application of green roof on a different building design. The results revealed that green roofs could offer significant savings on the heating and cooling load of buildings with uninsulated roofs but the heating and cooling energy requirements did not reduce a lot in buildings where a $50 \mathrm{~mm}$ insulation layer is also applied on the roof. The same conclusion was obtained when the building was simulated with free float conditions and results of indoor air temperatures were extracted for days of peak thermal loads.

\section{References}

Alexandri E., Jones P., 2008. Temperature decreases in an urban canyon due to green walls and green roofs in diverse climates. Building and Environment, Vol 43, pp. 480-493. 
Banting D., Doshi H., Li J., Missios P., Au A., Currie B.A., Verrati M., 2005. Report on the Environmental Benefits and Costs of Green Roof Technology for the City of Toronto. Report prepared for City of Toronto and Ontario Centres of Excellence - Earth and Environmental Technologies (OCE-ETech) by Ryerson University. Available at: http://www.toronto.ca/greenroofs/pdf/fullreport103105.pdf (Accessed 1 January 2013).

Brenneisen S., 2003. The benefits of biodiversity from green roofs - key design consequences. Proceedings of 1st North American Greenroof Conference: Greening Rooftops for Sustainable Communities, pp. 323-329, Chicago, USA.

Castleton H.F., Stovin V., Beck S.B.M. Davison J.B., 2010. Green roofs; building energy savings and the potential for retrofit. Energy and Buildings, Vol 42, pp. 1582-1591.

Feng C., Meng Q., Zhang Y., 2010. Theoretical and experimental analysis of the energy balance of extensive green roofs. Energy and Buildings, Vol 42, pp. 959-965.

Jaffal I., Ouldboukhitine S-E., Belarbi R., 2012. A comprehensive study of the impact of green roofs on building energy performance. Renewable Energy, Vol 43, pp. 157-164.

Jim C.Y., Tsang S.W., 2011. Biophysical properties and thermal performance of an intensive green roof. Building and Environment, Vol 46, pp. 1263-1274.

International Energy Agency (IEA), 2012. $\mathrm{CO}_{2}$ emissions from fuel combustion highlights. IEA Statistics, 2012 edition.

Kelly N.J., 1998. Towards a design environment for building-integrated energy systems: the integration of electrical power flow modelling with building simulation. PhD Thesis, Glasgow: University of Strathclyde.

Mentens J., Raes D., Hermy M., 2006. Green roofs as a tool for solving the rainwater runoff problem in the urbanized $21^{\text {st }}$ century? Landscape and Urban Planning, Vol77, pp. 217-226.

Onmura S., Matsumoto M., Hokoi S., 2001. Study on evaporative cooling effect of roof lawn gardens. Energy and Buildings, Vol 33, pp. 653-666.

Palomo D. B.E., 1998. Analysis of the green roofs cooling potential in buildings. Energy and Buildings, Vol 27, pp. 179-193.

Sailor D.J., 2008. A green roof model for building energy simulation programs. Energy and Buildings, Vol 40, pp. 1466-1478. 
Strachan P., Kokogiannakis G., Macdonald I., 2008. History and development of validation with the ESP-r simulation program, Building and Environment, Vol 43, pp. 601-609.

Susca T., Gaffin S.R., Dell’Osso G.R., 2011. Positive effects of vegetation: Urban heat island and green roofs. Environmental Pollution, Vol 159, pp. 2119-2126.

Tabares-Velasco P.C., Srebric J., 2012. A heat transfer model for assessment of plant based roofing systems in summer conditions. Building and Environment, Vol 49 , pp. $310-323$.

Teemusk A., Mander U., 2007. Rainwater runoff quantity and quality performance from a green roof: the effects of short-term events. Ecological Engineering, Vol 30, pp. 271-277.

Wong N.H., Chen Y., Ong C.L., Sia A., 2003. Investigation of thermal benefits of rooftop garden in the tropical environment. Building and Environment, Vol 38, pp. 261-270.

Yang J., Yu Q., Gong P., 2008. Quantifying air pollution removal by green roofs in Chicago. Atmospheric Environment, Vol 42, pp. 7266-7273. 